\title{
EFFECT OF SUPPLY CHAIN PRACTICES ON OPERATIONAL PERFORMANCE IN THE CASE OF THE BREWERY INDUSTRY
}

\author{
Tigist Wolde Gebre \\ Research Scholar, School of Management Studies \\ Punjabi University, Patiala, Punjab, India \\ Dr. Rajwinder Singh \\ Assistant Professor, School of Management Studies \\ Punjabi University, Patiala, Punjab, India
}

\begin{abstract}
The main aim of this empirical research is to investigate the direct effect of supply chain practices (SCPS) on the operational performance of the Ethiopian Brewery Industry. This research conceptualizes and develops six dimensions of SCPS (viz., strategic supplier partnership, level of information sharing, quality of information sharing, customer relationship, internal lean practices, and mass customization) and tests the relationships between SCPS (independent variables) and OP (dependent variable). The quantitative research approach and the descriptive study design were adopted for the study. The simple random sampling method was used to select respondents from one of the well-known brewery industry in Ethiopia. Data for the study were collected from 113 respondents by using a five-point Likert scale survey questionnaire. The study employed the partial least squares (PLS) method in the estimation of the structural equation model (SEM) effect in SCPs on OP. A measurement PLS model is developed using SmartPLS software (version 3) and refined with reliability and validity tests. The results show that strategic supplier partnership and customer relationship management are positively and significantly related to $O P$ of the Ethiopian Brewery Industry. The results indicate that higher levels of SCPs can lead to enhanced OP. The paper concludes that efficient SCPs will result in more OP. The result of this study contributes to the literature on SCPs by analysing the effect of SCPS on the OP towards a Brewery Industry capabilities perspective in a specific Ethiopian industrial context.
\end{abstract}


Key words: Supply chain practice, Operational performance, Brewery industry.

Cite this Article: Tigist Wolde Gebre and Rajwinder Singh, Effect of Supply Chain Practices on Operational Performance in the Case of the Brewery Industry, International Journal of Management, 11(12), 2020, pp 521-530.

http://iaeme.com/Home/issue/IJM?Volume=11\&Issue $=12$

\section{INTRODUCTION}

As the opposition moves past a solitary firm into the supply chain (SC), firms started to understand that it isn't sufficient, on the off chance that they just focus on improve performance all through inside practices inside their own firm. As indicated by Li et al. (2006) [1] the turn of events and execution of SC practices (SCPs) can expand client esteem, pick up competitive advantages in the commercial center, and get great benefits also. Subsequently, SCPs turns out to be progressively significant. Numerous firms have begun perceiving that SCPs are the fundamental factor to make a sustainable competitive edge for their items as well as services in an undeniably jam-packed commercial center.

\section{THEORETICAL RESEARCH FRAMEWORK}

Figure 1 represents the hypothetical research framework created for this study. The framework permits the comprehension of the forerunners and results of SCPs as portrayed by the causal connections among SCPs and operational execution (OP). SCPs are conceptualized through a six-dimensional build (independent variables) and industry OP (dependent variable). These measurements were tried and approved by different researchers ( $\mathrm{Li}$ et al., 2006; Cook et al., 2011) [1, 2], and were considered as significant variables that influence manufacturing firm performance.

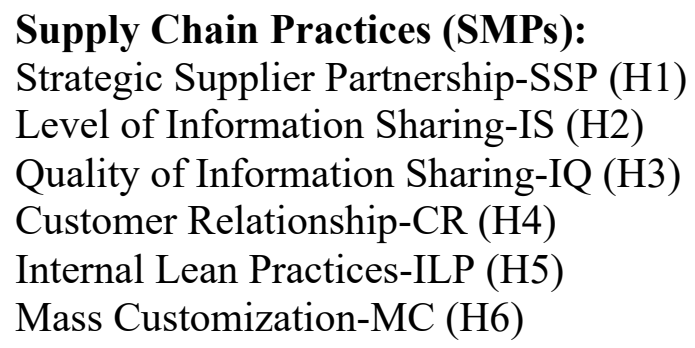

Figure 1. Research framework model

Operational Performance (OP)

(Dependent Factor)

\section{INDUSTRY OPERATIONAL PERFORMANCE}

Supply chain management (SCM) incorporates all activities, which are associated with arranging and the executives, sourcing and acquirement, transformation and all coordination's the management activities just as coordination and joint effort with channel accomplices (Soosay et al., 2008) [3].

As indicated by Feldmann and Muller (2003) [4] there is no commonly acknowledged meaning of SCM in the literature. SCM definitions are grouped into three classifications: integrated logistics management, purchasing and supply management, and integrated SCM.

Strategic supplier partnership is characterized by Li et al. (2006) [1] as "the drawn-out connection between the firms and its suppliers". It is intended to improve the operational and key endeavors and capacities of individual partaking firms to accomplish their objectives ( $\mathrm{Li}$ 
et al., 2005) [5]. A viable supplier partnership is a basic segment of driving edge SC (Arawati \& Zafaran, 2008) [6].

Level of information sharing is characterized by Li et al. (2006) [1] as "the degree to which basic and restrictive information/data is imparted to one's SC accomplice". Expanding consideration regarding data mix prompts the expansion of the foundation of strategic SC accomplices (Zhou \& Benton, 2007) [7]. This measurement incorporates aspects, for example, practicality, precision, ampleness and believability of data traded (Li et al., 2006) [1].

Given the significance that quality of data sharing has been given in the scholarly literature corresponding with its impact of SCM (Li et al., 2006; Li \& Lin, 2006) [1, 8], this has been incorporated as one of the components of the SCPs develop.

As per Lee et al. (2007) [9], customer/client relationship management is "related about planning, actualizing, and assessing fruitful connections among suppliers and beneficiaries either upstream or downstream of the SC". Lean has picked up prominence in a wide scope of modern areas, beyond manufacturing, all around the globe (Garza-Reyes et al., 2012) [10].

Lean is centered on recognizing and disposing of waste all through an item's whole value stream, expanding inside the firm as well as alongside its whole SC network (Boyle \& Scherrer, 2009) [11].

\section{INDUSTRY OPERATIONAL PERFORMANCE}

Firms' performance is a composite build that shows the business performance of an organization. In particular, it alludes to how well a firm satisfies its monetary and market objectives (Li et al., 2006) [1]. The momentary destinations of SCM are chiefly to diminish stock, increment profitability and decrease the process duration of items and services, while long-term targets are to build benefits, entering new business sectors, expanding quality, and increment market share for all units of the SC (Tan et al., 1998) [12].

Operation performance alludes to the capacity of a firm in decreasing administration costs, request time, lead-time, improving the adequacy of utilizing raw material and distribution limit (Heizer et al., 2008) [13]. Operation performance has a significant importance to firms, it assists with improving the adequacy of production activities and to make top notch items (Kaynak, 2003) [14], prompting expanded income and benefit for firms.

\section{HYPOTHESES}

Based on the literature reviewed and research framework following hypotheses are proposed and tested with the help of SmartPLS (version 3).

Hypothesis-H1: Brewery industry with high levels of strategic supplier partnership practices will have high levels of operational performance.

Hypothesis-H2: Brewery industry with high levels of information sharing practices will have high levels of operational performance.

Hypothesis-H3: Brewery industry with high levels of quality of information practices sharing will have high levels of operational performance.

Hypothesis-H4: Brewery industry with high levels of customer relationship management practices will have high levels of operational performance.

Hypothesis-H5: Brewery industry with high levels of internal lean practices will have high levels of operational performance. 


\section{RESEARCH METHODOLOGY}

The sample population for this study consists of the one Ethiopian Brewery Industry located in Addis Ababa (Ethiopia). The total population size was 2414 (permanent employees), simple random sampling method was adopted and the sample size for the study was 119 respondents (viz., from marketing, production, finance, supply chain managers, operators, and distributors) working with brewery industry.

The primary data collection instrument used for this research is a well-structured questionnaire (five point Likert scale). The variables needed for the survey questionnaire were generated through the literature review. Initially SCPs includes, strategic supplier partnership (SSP) consists of 10 items, level of information sharing (IS) consists of 7 items, quality of information sharing (IQ) consists of 5 items, customer relationship (CR) management consists of 8 items, internal lean practices (ILP) consists of 7 items, and mass customization (MC) consists of 5 items and operational performance (OP) consists of 7 items.

The quantitative approach was adopted in analysing data and making interpretations. This study employed partial least squares path structural equation modelling (PLS-SEM) method to estimate structural model because PLS-SEM can achieve a high level of statistical power even with a relatively small sample size (Hair et al., 2013) [15].

Assessment of the model's performance was done by interrogating its convergent and discriminant validity, average variance extracted (AVE) and composite reliability (CR). In measuring discriminant validity, first considered factor loadings, then further to also look at Fornell-Lacker criterion, and finally considered the heterotrait-monotrait ratio of correlations (HTMT) ratio. Table 1 shows the various construct reliability and validity measurement criteria should meet the recommended threshold indicated.

Table 1. Measurement criteria thresholds

\begin{tabular}{ll}
\hline Measurement Criteria & Cut-Off \\
\hline Factor loading (Hair et al., 1998) [16] & $\geq .70$ \\
Composite reliability (Bagozzi \& Yi, 1988) [17] & $\geq .60$ \\
Average variance extracted (Rodgers \& Pavlou, 2003) [18] & $>.50$ \\
Cronbach's alpha (Henseler et al., 2009) [19] & $\geq .70$ \\
HTMT ratio (Hair et al., 1998) [16] & $<.85$ \\
SRMR (Henseler et al., 2016) [20] & $<.08$ \\
Variance inflation factor (VIF) Hair et al. (2011; 2017) [21,22] & $<5$ \\
\hline
\end{tabular}

\section{RESULTS}

This study employed PLS-SEM method to estimate the structural model as per Hair et al. (1998) [16]. Figure 1 shows initial model generated through SmartPLS having initial factor loading for independent and dependent factors. From Table 2, it is evident that the model achieves reliability since the Cronbach's alpha and CR were found to be within the range .863 to .936 and .905 to .954 respectively thereby suggesting that the constructs have high internal consistency and reliability.

Mass customization (MC*) has been totally removed due to Cronbach's alpha is .664 and average variance extracted (AVE) was found to be .399 , which are less than the recommended cut-off value (Table 1). From Table 3, the AVEs of the constructs were within the range .613 to .839 indicating that the constructs have convergent validity. The AVEs were all above the threshold of .5 as recommended by Rodgers and Pavlou (2003) [18]. 


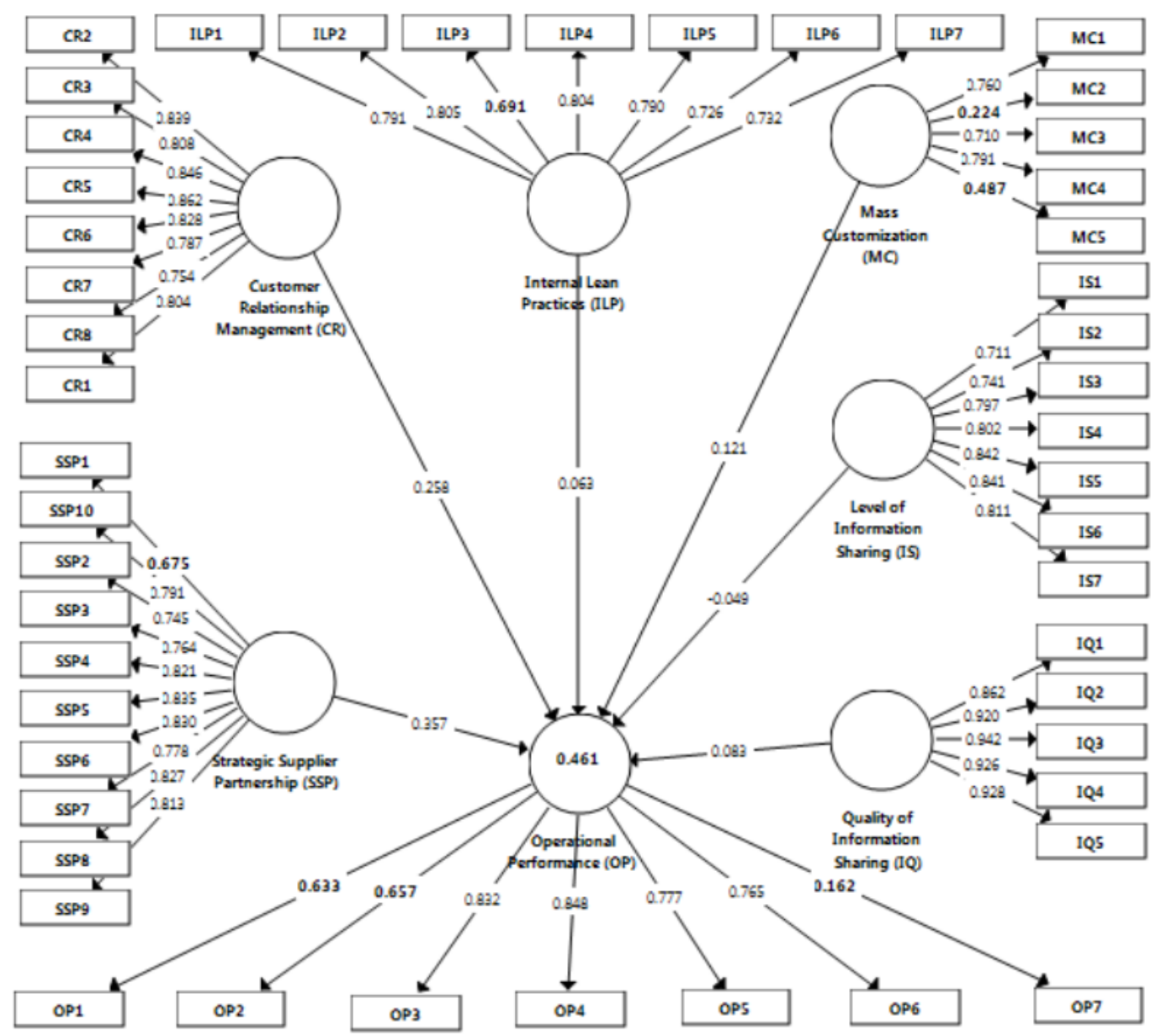

Figure 2. Initial model (Output SmartPLS)

Table 2. Construct reliability and validity

\begin{tabular}{lccc}
\hline Construct & Alpha & CR & AVE \\
\hline Customer Relationship Management (CR) & .928 & .941 & .667 \\
Internal Lean Practices (ILP) & .875 & .905 & .613 \\
Level of Information Sharing (IS) & .903 & .922 & .629 \\
Quality of Information Sharing (IQ) & .936 & .954 & .839 \\
Strategic Supplier Partnership (SSP) & .921 & .935 & .642 \\
Mass Customization (MC*) & .664 & .746 & .399 \\
Operational Performance (OP) & .863 & .907 & .709 \\
\hline
\end{tabular}

The Fornell-Lacker criterion indicated in Table 3, the factor loadings indicated in Table 4 and the HTMT ratio presented in Table 5 suggests that the constructs and model as a whole has discriminant validity and were all under the cut-off value. The HTMT should be lower than .85 (more strict threshold) or .90 (more lenient threshold) or significantly smaller than 1 (Hair et al., 1998) [16]. Table 3 indicates that the model has discriminant validity since all the square roots of the AVEs are larger than the correlations of the latent variables in the model.

Table 4 presents the factor loading of the constructs used in this research study. All factor loadings were above .712 , which are well above the suggested value of .70 recommended as per Hair et al. (1998) [16].

All constructs in the model were well below the value of .85 suggested by Clark and Watson (1995) [23] and Kline (2018) [24], since the highest value is .770 of IQ (Table 5). As per Hair et al. (2011) [21] and Hair et al. (2017) [22] VIF values above 5 are regarded as indications of problematic multi-collinearity. In this study the VIF values for the indicators of 
the composite models range from 1.910 to 4.821 (Table 6), suggesting that multi-collinearity is not a problem in this data.

Table 3. Fornell-larcker criterion

\begin{tabular}{lllllll}
\hline Factors & CR & ILP & IS & OP & IQ & SSP \\
\hline Customer Relationship (CR) & .817 & & & & & \\
Internal Lean Practices (ILP) & .479 & .783 & & & & \\
Level of Information Sharing (IS) & .349 & .394 & .793 & & & \\
Operational Performance (OP) & .562 & .421 & .249 & .842 & & \\
Quality of Information Sharing (IQ) & .354 & .398 & .699 & .322 & .916 & \\
Strategic Supplier Partnership (SSP) & .571 & .494 & .300 & .582 & .387 & .801 \\
\hline
\end{tabular}

Table 4. Factor loadings

\begin{tabular}{|c|c|c|c|c|c|c|c|c|}
\hline Factors & CR & IS & Factors & IQ & OP & Factors & SSP & ILP \\
\hline CR1 & .800 & & IQ1 & .883 & & SSP10 & .796 & \\
\hline CR2 & 837 & & IQ2 & .932 & & SSP2 & .739 & \\
\hline CR3 & .805 & & IQ4 & .930 & & SSP3 & .764 & \\
\hline CR4 & .847 & & IQ5 & .917 & & SSP4 & .831 & \\
\hline CR5 & .862 & & OP3 & & .887 & SSP5 & .854 & \\
\hline CR6 & .829 & & OP4 & & .904 & SSP6 & .842 & \\
\hline CR7 & .793 & & OP5 & & .814 & SSP7 & .783 & \\
\hline CR8 & .756 & & OP6 & & .755 & SSP9 & .794 & \\
\hline IS1 & & .712 & & & & ILP1 & & .774 \\
\hline IS2 & & .747 & & & & ILP2 & & .805 \\
\hline IS3 & & .800 & & & & ILP4 & & .810 \\
\hline IS4 & & .797 & & & & ILP5 & & .804 \\
\hline IS5 & & .843 & & & & ILP6 & & .749 \\
\hline IS6 & & .839 & & & & ILP7 & & .753 \\
\hline IS7 & & .806 & & & & & & \\
\hline
\end{tabular}

Table 5. Heterotrait-Monotrait ratio (HTMT)

\begin{tabular}{lcccccc}
\hline Factors & CR & ILP & IS & OP & IQ & SSP \\
\hline Customer Relationship Management (CR) & - & & & & & \\
Internal Lean Practices (ILP) & .534 & & & & & \\
Level of Information Sharing (IS) & .367 & .441 & & & & \\
Operational Performance (OP) & .612 & .471 & .270 & & & \\
Quality of Information Sharing (IQ) & .382 & .436 & .770 & .363 & & \\
Strategic Supplier Partnership (SSP) & .610 & .544 & .340 & .629 & .419 & - \\
\hline
\end{tabular}

The R-square (Table 7) explains the variance of the endogenous variable predicted explained by the exogenous variable. The F-square explains the effect size and according to Cohen (1988) [25] .02-.15, .15-.35, and $\geq .35$ suggest small, medium, and large effects respectively.

Table 7 shows that SCPs and OP have R-square value of .427. Moreover, the R-square value for OP explained by the SCPs is .427 , indicating that the SCPs can explain a large amount of variance in OP. Therefore, it can be said that SCPs suggested in this study have important role in improving OP.

The effect size, which is connoted by F-square, shows that there are moderate effects (Cohen, 1988) [25] of CR is .103 and SSP is .122 respectively on OP. For overall approximate model fit (estimated model) assessment criteria is standardized root mean square residual (SRMR) should be less than .08 which is met in this study (i.e., .078). It is observed that a SRMR value is less than .08; hence the model is meeting the goodness of fit (GoF) criteria. 
Tigist Wolde Gebre and Rajwinder Singh

Table 6. Variance inflation factor (VIF)

\begin{tabular}{lllllllllc}
\hline Items & VIF & Items & VIF & Items & VIF & Items & VIF & Items & VIF \\
\hline CR1 & 3.640 & ILP1 & 2.191 & IQ4 & 4.304 & IS7 & 2.325 & SSP9 & 2.695 \\
CR2 & 4.061 & ILP2 & 1.910 & IQ5 & 3.704 & SSP10 & 2.414 & OP3 & 4.172 \\
CR3 & 2.901 & ILP4 & 2.374 & IS1 & 2.275 & SSP2 & 2.752 & OP4 & 4.323 \\
CR4 & 3.805 & ILP5 & 2.134 & IS2 & 2.464 & SSP3 & 2.860 & OP5 & 2.136 \\
CR5 & 3.670 & ILP6 & 2.023 & IS3 & 2.728 & SSP4 & 3.417 & OP6 & 1.923 \\
CR6 & 2.657 & ILP7 & 2.051 & IS4 & 3.842 & SSP5 & 3.503 & & \\
CR7 & 2.864 & IQ1 & 3.116 & IS5 & 4.482 & SSP6 & 2.712 & & \\
CR8 & 2.277 & IQ2 & 4.821 & IS6 & 3.925 & SSP7 & 2.253 & & \\
\hline
\end{tabular}

Table 7. Path estimations

\begin{tabular}{lcccccc}
\hline Factor & \multicolumn{3}{c}{ R-Square } & \multicolumn{3}{c}{ Adjusted R- Square } \\
\hline OP & \multicolumn{3}{c}{.427} & & \multicolumn{2}{c}{.401} \\
\hline Path & $\begin{array}{c}\text { Beta } \\
\text { Coefficient }\end{array}$ & $\begin{array}{c}\text { Standard } \\
\text { Deviation }\end{array}$ & $\begin{array}{c}\text { T- } \\
\text { Statistics }\end{array}$ & $\begin{array}{c}\text { P- } \\
\text { Values }\end{array}$ & $\begin{array}{c}\text { F- } \\
\text { Square }\end{array}$ & $\begin{array}{c}\text { Hypothesis } \\
\text { Testing }\end{array}$ \\
\hline CR -> OP & .313 & .131 & 2.377 & .017 & .103 & H1: Accepted \\
ILP -> OP & .092 & .108 & .849 & .396 & .010 & H2: Rejected \\
IS -> OP & -.054 & .135 & .404 & .686 & .003 & H3: Rejected \\
IQ -> OP & .080 & .121 & .66 & .509 & .005 & H4: Rejected \\
SSP -> OP & .344 & .121 & 2.847 & .004 & .122 & H5: Accepted \\
\hline
\end{tabular}

PLS-SEM does not generate overall GoF indices, and R-square value is considered as the primary way to evaluate the explanatory power of the model (Henseler et al., 2016) [20]. However, GoF index for PLS-SEM was used to assess the model fit. This GoF is measured by using the geometric mean value of the average communality score (AVE values) and the average R-square values (for endogenous constructs) and is calculated using GoF $=\sqrt{\mathrm{AVE} \times \mathrm{R}^{2}}$.

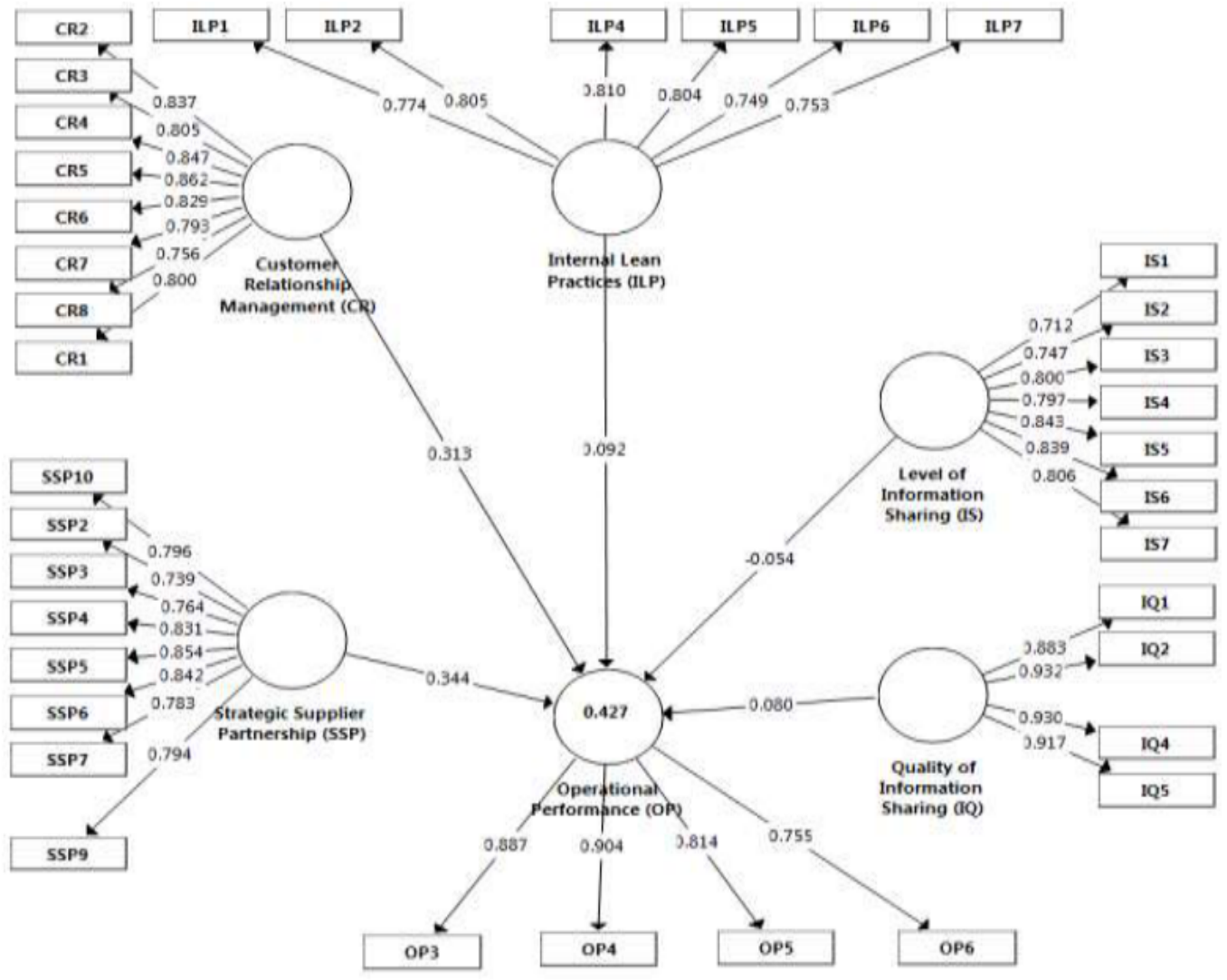

Figure 3. Measurement model assessment 
Wetzels et al. (2009) [26] reported following cut-off values for assessing the results of the GoF analysis: GoFsmall $=.1$; GoFmedium $=.25$; GoFlarge $=.36$. GoF index was calculated, which yielded a GoF index value of .540, which indicates a very good (GoFlarge) model fit.

From Table 7 and Figure 3, it is revealed that two hypotheses in the study are supported. This means that hypothesis 1 , which states H1: Brewery industry with high levels of SSP practices will have high levels of OP is supported $(\beta=.313, \mathrm{p}<.05, \mathrm{t}=2.847$; Table 7 , Figure 3). Ragatz et al. (1997) [27] sated that SSP can reduce time to market. Vonderembse and Tracey (1999) [28] showed that a good relationship with suppliers is useful for reducing order-time and rate of late orders. Moreover, effective supplier management can cut off inventory, waste and safety inventory level (Easton \& Jarrell, 1998; Yeung, 2008) [29, 30].

Furthermore, hypothesis 4 , which also states H4: Brewery industry with high levels of CR practices will have high levels of OP is supported $(\beta=0.344, p<0.05, t=2.377$; Table 7 , Figure 3). The implementation of customer focus practice helps companies to better understand customer expectations and market opportunities (Lakhal et al., 2006) [31]. Based on that, industry can be active in planning for purchasing, production, delivery, etc. For instance, firms can balance supply and demand, reducing variance in processes (Lee et al., 1997) [32].

\section{CONCLUSIONS}

This study provided empirical evidences that prove importance of the SCPs in improving OP. Accordingly these SCPs could explain $42.7 \%$ variance of OP. This is a remarkable rate because not only the SCPs suggested in this study, OP is also impacted by others, such as operating environment, capital, technology, equipment, human resource, information, etc.

Industry which has limited resources for equipment investment, technological innovations will be able to remarkably improve OP by implementing these SMPs. In other words, in the same conditions of finance, technology, equipment, environment, etc., those that can well address these SCPs will have higher OP. Moreover, this study explored the relationship between each SCPs and OP. In particular, CR and SSP both directly impact on OP.

\section{REFERENCES}

[1] Li, S., Ragu-Nathan, B., Ragu-Nathan, T. S. and Rao, S. S. The impact of supply chain management practices on competitive advantage and organizational performance. Omega, 34(2), 2006, pp. 107-124.

[2] Cook, L., D., Heiser, S. and Sengupta, K. The moderating effect of supply chain role on the relationship between supply chain practices and performance. International Journal of Physical Distribution and Logistics Management, 41(2), 2011, pp. 104-134.

[3] Soosay, C., Hyland, P. and Ferrer, M. Supply chain collaboration: Capabilities for continuous innovation. Supply Chain Management: An International Journal, 13(2), 2008, pp. 160-169.

[4] Feldmann, M. and Muller, S. An incentive scheme for true information providing in supply chains. Omega, 31(2), 2003, pp. 63-73.

[5] Li, S., Rao, S. S., Ragu-Nathan, T. S. and Ragu-Nathan, B. Development and validation of a measurement instrument for studying supply chain management practices. Journal of Operations Management, 23(6), 2005, pp. 618-641.

[6] Arawati, A. and Zafaran, H. The strategic supplier partnership in a supply chain management with quality and business performance. International Journal of Business and Management Science, 1(2), 2008, pp. 129-145.

[7] Zhou, H. and Benton, Jr., W. C. Supply chain practice and information sharing. Journal of Operations Management, 25(6), 2007, pp. 1348-1365. 
[8] Li, S. and Lin, B. Accessing information sharing and information quality in supply chain management. Decision Support Systems, 42(3), 2006, pp. 1641-1656.

[9] Lee, C., Kwon, I. and Severance, D. Relationship between supply chain performance and degree of linkage among supplier, internal integration, and customer. Supply Chain Management: An International Journal, 12(6), 2007, pp. 444-452.

[10] Garza-Reyes, J. A., Parkar, H. S., Oraifige, I., Soriano-Meier, H. and Harmanto, D. An empirical-exploratory study of the status of lean manufacturing in India. International Journal of Business Excellence, 5(4), 2012, pp. 395-412.

[11] Boyle, T. A. and Scherrer, R. M. An empirical examination of the best practices to ensure manufacturing flexibility. Journal of Manufacturing Technology Management, 20(3), 2009, pp. 348-366.

[12] Tan, K. C., Kannan, V. R. and Handfield, R. B. Supply chain management: Supplier performance and firm performance. International Journal of Purchasing and Materials Management, 34(3), 1998, pp. 2-9.

[13] Heizer, J. H., Render, B., \& Weiss, H. J. Principles of Operations Management, Pearson Prentice Hall, 2008.

[14] Kaynak, H. The relationship between total quality management practices and their effects on firm performance. Journal of Operations Management, 21, 2003, pp. 405-435.

[15] Hair, J. F., Ringle, C. M. and Sarstedt, M. Partial least squares structural equation modeling: Rigorous applications, better results and higher acceptance. Long Range Planning, 46(1-2), 2013, pp. 1-12.

[16] Hair, J. F., Blac, W. C., Babin, B. J., Anderson, R.E., Tatham, R. L. Multivariate Data Analysis, 5(3), 207-219. Upper Saddle River: Prentice Hall, 1998.

[17] Bagozzi, R. P. and Yi, Y. On the evaluation for structural equation models. Journal of the Academy of Marketing Science, 16, 1988, pp. 74-94.

[18] Rodgers, W. and Pavlou, P. Developing a predictive model: A comparative study of the partial least squares vs. maximum likelihood techniques. Riverside: Graduate School of Management, University of California, Riverside, 2003.

[19] Henseler, J., Ringle, C. M. and Sinkovics, R. R. The use of partial least squares path modeling in international marketing. Advances in International Marketing, 20, 2009, pp. 277-320.

[20] Henseler, J., Hubona, G. and Ray, P. A. Using PLS path modeling in new technology research: Updated guidelines. Industrial Management \& Data Systems, 116(1), 2016, pp. 220 .

[21] Hair, J., Ringle, C. and Sarstedt, M. PLS-SEM: Indeed a silver bullet. Journal of Marketing Theory and Practice, 19(2), 2011, pp. 139-151.

[22] Hair, J., Hult, G., Ringle, C. and Sarstedt, M. A Primer on Partial Least Squares Structural Equation Modeling (PLS-SEM), 2nd Edition, Sage, Thousand Oaks, USA, 2017.

[23] Clark, L. A. and Watson, D. Constructing validity: Basic issues in objective scale development. Psychological Assessment, 7(3), 1995, pp. 309-319.

[24] Kline, R. B. Principles and Practice of Structural Equation Modeling. New York: Guilford Press, 2011.

[25] Cohen, J. Statistical Power Analysis for Behavioral Sciences, 2nd Edition, Erlbaum, Hillsdale, USA, 1988.

[26] Wetzels, M., Odekerken-Schröder, G. and Van Oppen, C. Using PLS path modeling for assessing hierarchical construct models: Guidelines and empirical illustration. MIS Quarterly, 33(1), 2009, pp. 177-195. 
Effect of Supply Chain Practices on Operational Performance in the Case of the Brewery Industry

[27] Ragatz, G. L., Handfield, R. B. and Scannell, T. V. Success factors for integrating suppliers into new product development. Journal of Product Innovation Management, 14(3), 1997, pp. 190-202.

[28] Vonderembse, M. A. and Tracey, M. The impact of supplier selection criteria and supplier involvement on manufacturing performance. Journal of Supply Chain Management, 35, 1999, 33-39.

[29] Easton, G. S. and Jarrell, S. L. The effects of total quality management on corporate performance: An Empirical Investigation. The Journal of Business, 71, 1998, pp. 253-307.

[30] Yeung, A. C. L. Strategic supply management, quality initiatives, and organizational performance. Journal of Operations Management, 26, 2008, pp. 490-502.

[31] Lakhal, L., Pasin, F. and Limam, M. Quality management practices and their impact on performance. International Journal of Quality \& Reliability Management, 23, 2006, pp. 625646.

[32] Lee, H., Padmanabhan, P. and Whang, S. The bullwhip effect in supply chains. Sloan Management Review, 38, 1997, pp. 93-102. 